\title{
STRATEGI KOMUNIKASI DALAM INTERAKSI DENGAN MAHASISWA PERTUKARAN ASING
}

\author{
Nabilla Kusuma Vardhani ${ }^{1}$, Agnes Siwi Purwaning Tyas ${ }^{2}$ \\ 1,2Program Studi Bahasa Inggris/Departemen Bahasa, Seni dan Manajemen Budaya/Sekolah Vokasi, \\ Universitas Gadjah Mada, Indonesia \\ Email: 1nabilla.kusuma.v@mail.ugm.ac.id \\ Email:2agnesiwi@ugm.ac.id
}

\begin{abstract}
ABSTRAK
Suatu proses komunikasi dapat dianggap berhasil ketika komunikan menerima dan memahami pesan sebagaimana yang dimaksud oleh komunikator. Komunikasi yang efektif ini akan menghasilkan tercapainya tujuan komunikasi. Namun demikian, komunikasi yang efektif akan sulit terjadi ketika kedua lawan bicara tidak memiliki bahasa asli yang sama. Hal itu terjadi karena hambatan bahasa dapat mempengaruhi proses pemahaman pesan ketika komunikasi terjadi. Untuk mengatasi masalah tersebut, komunikator menerapkan beberapa strategi komunikasi. Studi komparatif ini menggunakan observasi dan wawancara untuk menguji strategi komunikasi yang digunakan oleh mahasiswa Bahasa Inggris tahun pertama dan ketiga di Universitas Gadjah Mada Indonesia selama berinteraksi lisan dalam bahasa Inggris dengan mahasiswa pertukaran dari Cheng Du Textile College China. Tujuan dari penelitian ini adalah untuk mengamati bagaimana mahasiswa tahun pertama dan ketiga di UGM mengatasi masalah komunikasi mereka ketika berbicara dengan mahasiswa CDTC yang bahasa aslinya bukan Bahasa Inggris kemudian menjadikan data penelitian ini sebagai masukan untuk mengembangkan kurikulum berikutnya. Penulis menggunakan strategi komunikatif Tarone untuk mengidentifikasi strategi mahasiswa. Hasilnya menunjukkan bahwa 'Penerjemahan Literal' tidak digunakan oleh mahasiswa bahasa Inggris ketika berkomunikasi dengan siswa pertukaran, 'Bicara Bertele-tele' dan 'Pengabaian Pesan' hanya digunakan oleh mahasiswa tahun ketiga, 'Memohon Bantuan' dan 'Penghindaran Topik' hanya digunakan oleh mahasiswa tahun pertama, strategi yang paling banyak digunakan mahasiswa tahun ketiga adalah 'Meniru' dan 'Penciptaan Kata', dan strategi yang paling banyak digunakan mahasiswa tahun pertama adalah 'Perkiraan' and 'Meniru'.
\end{abstract}

Kata kunci: komunikasi efektif, mahasiswa Bahasa Inggris SV UGM, strategi komunikasi

\section{PENDAHULUAN}

Komunikasi adalah suatu proses di mana dua orang atau lebih membentuk atau melakukan pertukaran informasi dengan satu sama lainnya, yang pada gilirannya akan tiba pada saling pengertian yang saling mendalam (Rogers \& Kincaid, 1981). Dalam proses komunikasi, komunikator menyampaikan pesan kepada komunikan dengan tujuan agar komunikan mengerti yang dimaksud oleh komunikator. Yang perlu diperhatikan dalam proses komunikasi adalah, pesan yang diterima oleh komunikan harus sesuai dengan pesan yang dimaksud dan disampaikan oleh komunikator. Dalam proses tersebut, tentunya ada berbagai aspek yang memengaruhi keberhasilan komunikasi. Aspek-aspek yang memengaruhi proses komunikasi dapat dimengerti lebih mudah dengan mengamati model komunikasi.

Model komunikasi yang dirumuskan oleh Harold D. Lasswell berbunyi: who, says what, in which channel, to whom, with what effect. Ini bermakna, model komunikasi meliputi (i) siapa yang menyampaikan, (ii) apa yang disampaikan, (iii) melalui saluran apa, (iv) kepada siapa, dan (v) apa pengaruhnya. Model komunikasi ini disebut oleh para ahli sebagai 'salah satu model yang terdahulu dan paling berpengaruh' (Shoemaker, 2003). Kelima aspek dalam model komunikasi tersebut dapat memengaruhi keberhasilan komunikasi. Misalnya, latar belakang komunikator akan memengaruhi gaya bicara, cara penyampaian, dan sebagainya. Hal ini berlaku juga bagi komunikator, di mana latar belakang komunikator akan memengaruhinya dalam memproses dan menginterpretasi pesan.

Pesan atau informasi apa yang disampaikan juga memiliki pengaruh dalam keberhasilan komunikasi; komunikator cenderung lebih mudah memahami apabila pesan yang disampaikan memiliki keterkaitan dengan dirinya. Kemudian terkait saluran yang 
digunakan, secara umum proses komunikasi dapat terjadi secara langsung (tatap muka) maupun tidak langsung (melalui media). Dalam proses komunikasi, dimungkinkan adanya gangguan komunikasi yang menyebabkan terhambatnya keberhasilan komunikasi. Yang terakhir dalam model komunikasi Lasswell adalah pengaruh yang diharapkan dari komunikasi. Menurut Effendy (2008:10), komunikasi adalah proses penyampaian pesan oleh komunikator kepada komunikan melalui media yang menimbulkan efek tertentu. Efek tersebut bervariasi dari memahami sampai melakukan sesuatu. Hal ini bisa dikaitkan dengan tujuan komunikasi itu sendiri. Menurut Dwijowijoto (2004:72), tujuan komunikasi adalah menciptakan pemahaman bersama atau mengubah persepsi, bahkan perilaku. Ditambahkan oleh Widjaja, tujuan komunikasi yaitu untuk menggerakkan orang lain untuk melakukan sesuatu (2002:66-67). Apabila antara tujuan dan efek tersebut sesuai, komunikasi dapat dikatakan berhasil.

Komunikasi yang berhasil seringkali disebut komunikasi yang efektif. Komunikasi yang efektif adalah saat komunikator berhasil menyampaikan apa yang dimaksud, di mana rangsangan yang disampaikan dan yang dimaksudkan oleh pengirim atau sumber, berkaitan erat dengan rangsangan yang ditangkap dan dipahami oleh penerima (Tubbs \& Moss, 2001). Gudykunst (1993) sebelumnya juga telah menegaskan dan menjelaskan hal yang sama bahwa, "communication is effective to the extent that the person interpreting the message attaches a meaning to the message that is relatively similar to what was intended by the person transmitting it." Dapat disimpulkan bahwa komunikasi yang efektif adalah saat pesan yang dimaksud oleh komunikator ditangkap maknanya dengan benar oleh komunikan.

Untuk mencapai komunikasi yang efektif, diperlukan strategi. Strategi komunikasi merupakan paduan dari perencanaan komunikasi dan manajemen komunikasi untuk mencapai suatu tujuan (Effendy, 2008:301). Strategi ini diperlukan untuk memperkecil kemungkinan terjadinya miskomunikasi. Miskomunikasi bisa terjadi karena berbagai faktor, salah satunya adalah perbedaan bahasa.

Dalam komunikasi antar pembelajar, strategi komunikasi merujuk pada strategi untuk mencapai pemahaman antar lawan bicara. Tarone (1981) mendefinisikan strategi komunikasi sebagai upaya sistematis oleh pembelajar untuk mengekspresikan maksud dalam bahasa target (bahasa yang dipelajari) ketika ia tidak dapat membentuk atau memilih kaidah bahasa target dengan tepat. Ellis (1994) mengungkapkan gagasan serupa bahwa strategi komunikasi adalah keterampilan prosedural yang digunakan pembelajar untuk mengatasi kekurangan kosa kata mereka. Hal ini dipertegas Cohen (2004) bahwa strategi komunikasi adalah upaya sistematis oleh pembelajar untuk mengekspresikan makna dengan bahasa target di mana aturan bahasa target yang sistematis belum terbentuk.

Untuk mengidentifikasi strategi komunikasi yang digunakan pembelajar di tingkat universitas (mahasiswa), penelitian ini mengadopsi strategi komunikasi milik Tarone yang meliputi:

(i) Paraphrase (parafrase)

(ii) Borrowing (meminjam)

(iii) Appeal for Assistance (memohon bantuan)

(iv) Mime (meniru)

(v) Avoidance (menghindar)

Teknik 'parafrase' dibagi menjadi tiga yaitu perkiraan, penciptaan kata, dan bicara bertele-tele. Dalam teknik 'meminjam', terdapat penerjemahan literal dan pengalihan bahasa. Sementara itu, teknik 'menghindar' meliputi penghindaran topik dan pengabaian pesan.

Strategi perkiraan terjadi ketika pembelajar sebagai komunikator menggunakan suatu kosa kata atau struktur dari bahasa target, meskipun ia tahu bahwa itu tidak benar, tetapi memiliki fitur semantik yang sama dengan kosa kata yang diinginkan. Misalnya, dalam bahasa target Bahasa Inggris, pembelajar ingin mengucapkan 'waterpipe', namun ia menyebut 'pipe'. Strategi kedua dari teknik 'parafrase' yaitu penciptaan kata, merujuk pada situasi di mana pembelajar sebagai komunikator menciptakan kata baru untuk mengkomunikasikan konsep yang dimaksud. Sementara itu, yang dimaksud dengan bicara bertele-tele yaitu ketika pembelajar mendeskripsikan karakteristik atau elemen dari sebuah objek atau aksi, alih-alih menggunakan kosa kata atau struktur dari bahasa target yang benar.

Dalam teknik 'meminjam', dikenal penerjemahan literal dan pengalihan bahasa. Penerjemahan literal adalah kondisi strategi di mana pembelajar menerjemahkan kata-per-kata dari bahasa 
asli mereka. Kemudian yang dimaksud dengan strategi pengalihan bahasa yaitu ketika mereka menggunakan bahasa asli, mencampurkan bahasa dalam menyampaikan pesan mereka.

Teknik yang ke tiga yaitu teknik 'memohon bantuan', di mana komunikator meminta bantuan dengan menanyakan istilah yang benar baik kepada lawan bicaranya maupun kepada orang ke tiga. Contohnya, dalam berkomunikasi dengan Bahasa Inggris, pembelajar sebagai komunikator akan menanyakan "What is this?" untuk menanyakan suatu istilah yang tak ia ketahui Bahasa Inggrisnya.

Berikutnya, komunikator bisa menggunakan strategi 'meniru' dalam berkomunikasi dengan bahasa asing. Strategi meniru terjadi saat komunikator menggunakan komunikasi nonverbal untuk menjelaskan konten leksikal maupun suatu aksi. Misalnya, alih-alih mengatakan 'applause', komunikator mempraktikkan tepuk tangan untuk menjelaskan kepada komunikan.

Teknik yang terakhir yaitu 'menghindar', terbagi atas dua strategi: penghindaran topik dan pengabaian pesan. Penghindaran topik terjadi saat komunikator memutuskan untuk tidak terlibat dalam pembicaraan yang topiknya tidak ia kuasai. Sementara pengabaian pesan terjadi saat komunikator sudah berusaha untuk berkomunikasi atau membicarakan sebuah konsep, namun tidak mampu untuk melanjutkan dan memutuskan untuk menghentikan pembicaraan.

Kesembilan strategi tersebut muncul dalam komunikasi dua arah dalam situasi pembelajaran bahasa asing. Dalam komunikasinya, sangat mungkin bagi komunikator untuk menggunakan lebih dari satu strategi dalam menjelaskan pesan agar komunikan dapat memahami dengan baik dan benar.

\section{METODE PENELITIAN}

Studi ini menggunakan metode observasi dan wawancara untuk membandingkan komunikasi yang dilakukan oleh pembelajar bahasa asing di tahun pertama dan tahun ke tiga dalam berkomunikasi dengan mahasisa pertukaran asing. Objek penelitian dari studi ini adalah mahasiswa Bahasa Inggris Sekolah Vokasi Universitas Gadjah Mada di tahun pertama (semester 1) dan tahun ke tiga (semester 5). Saat data ini diambil, mahasiswa tahun pertama adalah mahasiswa angkatan 2017 dan mahasiswa tahun ke tiga merupakan angkatan 2015.
Aktivitas yang diamati dan diteliti adalah strategi komunikasi mereka dalam berinteraksi dengan mahasiswa asing dari Cheng Du Textile College China yang sedang mengikuti program pertukaran mahasiswa asing di Sekolah Vokasi UGM. Dalam program tersebut, kedua belas mahasiswa dari CDTC China belajar bersama mahasiswa Bahasa Inggris Sekolah Vokasi UGM angkatan 2015 dan 2017. Para mahasiswa tersebut dituntut untuk membangun komunikasi karena di dalam kelas, seluruh mahasiswa memiliki kewajiban yang sama dalam mengerjakan tugas/proyek kelompok. Dengan demikian, mahasiswa Indonesia dan mahasiswa China 'dipaksa' untuk berinteraksi dengan Bahasa Inggris agar tercapai tujuan komunikasi (dalam hal ini yaitu untuk menyelesaikan tugas yang diberikan oleh dosen). Topik ini dipilih untuk membandingkan bagaimana strategi komunikasi dalam penggunaan Bahasa Inggris bagi mahasiswa baru dan mahasiswa yang sudah akan lulus.

Secara teknis, langkah pertama yang dilakukan peneliti adalah melakukan observasi terhadap para mahasiswa tersebut saat menjalani perkuliahan dengan mahasiswa asing. Pengamatan dilakukan di dua kelas yaitu kelas Berbicara I (untuk semester 1) dan kelas Manajemen Siaran TV (untuk semester 5). Selanjutnya, peneliti menyusun pertanyaan yang didasarkan pada teori strategi komunikasi sebagai dasar untuk melakukan wawancara mendalam kepada mahasiswa yang menjadi objek penelitian.

Dalam wawancara tersebut, peneliti mencatat kemudian menerjemahkan dan mengelompokkan hasil wawancara sesuai strategi komunikasi menurut teori yang dipilih oleh peneliti.

Adapun tujuan dari penelitian ini adalah untuk membandingkan strategi komunikasi yang digunakan oleh mahasiswa baru dan yang akan lulus. Data tersebut diharapkan dapat dijadikan salah satu masukan umum untuk menyusun program pertukaran mahasiswa asing berikutnya maupun sebagai bahan pertimbangan penyusunan kurikulum di Program Studi Bahasa Inggris Sekolah Vokasi UGM.

\section{HASIL DAN PEMBAHASAN}

Sebelum memasuki pembahasan tentang strategi komunikasi, secara umum peneliti menanyakan tentang apakah mahasiswa Bahasa Inggris Sekolah Vokasi UGM mengalami kesulitan dalam berinteraksi 
dengan mahasiswa pertukaran asing dari Cheng Du Textile College China. Hasil wawancara menunjukkan bahwa $75 \%$ mahasiswa tahun pertama menjawab 'ya' dan bagi mahasiswa tahun ke tiga, jumlahnya 54\%.

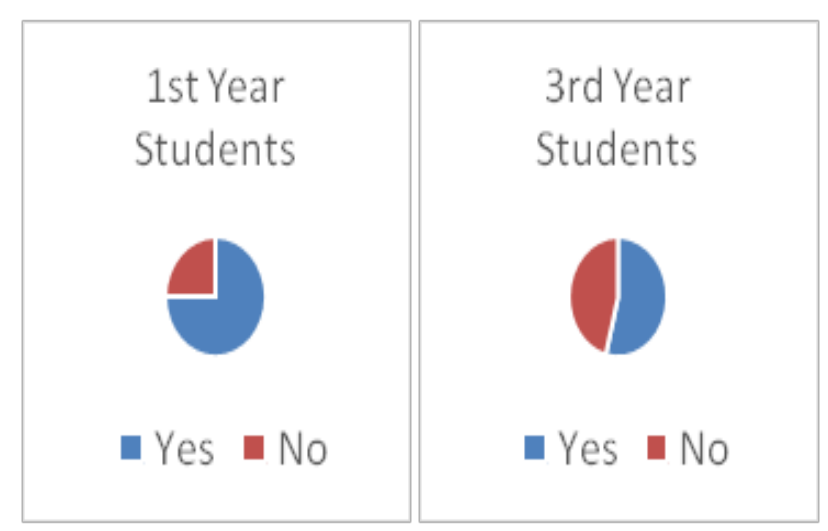

\section{Grafik 1. Jumlah mahasiswa Bahasa Inggris Sekolah Vokasi UGM yang merasa kesulitan dalam berinteraksi dengan mahasiswa pertukaran asing dari CDTC China}

Berdasarkan wawancara, kesulitan yang dialami oleh para mahasiswa Bahasa Inggris SV UGM disebabkan oleh aksen para mahasiswa CDTC China yang cenderung terpengaruh dengan bahasa asli mereka. Hal ini menyebabkan para mahasiswa SV UGM mengalami kesulitan dalam menangkap apa yang dimaksud oleh komunikator. Kesulitan lain yang ditemui dalam proses komunikasi berlangsung yaitu, terdapat momen-momen di mana mahasiswa dari SV UGM harus mengulang-ulang kalimat atau kata yang diucapkan karena mahasiswa CDTC China tidak mendengar secara jelas pesan yang disampaikan dalam Bahasa Inggris.

Untuk mengatasi kesulitan atau hambatan komunikasi tersebut, berikut ini akan dijelaskan strategi komunikasi yang dilakukan oleh mahasiswa Bahasa Inggris SV UGM agar tercapai komunikasi yang efektif selama proses belajar di Sekolah Vokasi UGM.

Dari teknik 'parafrase', strategi perkiraan lebih banyak digunakan oleh mahasiswa tahun pertama daripada tahun ke tiga. Sebaliknya, strategi penciptaan kata digunakan lebih banyak oleh mahasiswa tahun ke tiga daripada tahun pertama. Sementara itu, strategi bicara bertele-tele hanya digunakan oleh mahasiswa tahun ke tiga.

Kemudian dari teknik 'meminjam', strategi penerjemahan langsung tidak digunakan sama sekali, sementara pengalihan bahasa digunakan lebih banyak
Tabel 1. Strategi Komunikasi oleh mahasiswa Bahasa Inggris Sekolah Vokasi UGM dalam berinteraksi dengan mahasiswa pertukaran asing dari CDTC China

\begin{tabular}{cccc}
\hline Item & Branch & $1^{\text {st }}$ Year & $3^{\text {rd }}$ Year \\
\hline Paraphrase & Approximation & 4 & 2 \\
& Word Coinage & 2 & 4 \\
Borrowing & $\begin{array}{c}\text { Circumlocution } \\
\text { Literal Translation } \\
\text { Language Switch }\end{array}$ & 1 & 1 \\
Appeal for & & 2 & \\
Assistance & & 3 & 5 \\
Mime & & 1 & \\
Avoidance & Topic Avoidance & \\
\hline \multicolumn{3}{c}{ Message Abandonment } \\
\hline
\end{tabular}

pada mahasiswa tahun ke tiga. Dari teknik 'memohon bantuan', strategi meminta bantuan hanya terjadi pada mahasiswa tahun pertama. Dari teknik 'meniru', mahasiswa tahun ke tiga cenderung lebih banyak menggunakan strategi meniru daripada mahasiswa tahun pertama.

Teknik yang terakhir yaitu 'menghindar', strategi penghindaran topik hanya digunakan oleh mahasiswa tahun pertama sementara strategi pengabaian pesan hanya digunakan oleh mahasiswa tahun ke tiga. Secara umum, hasil dari penelitian yang dapat digarisbawahi yaitu:

1. Strategi penerjemahan langsung tidak digunakan sama sekali.

2. Strategi bicara bertele-tele dan pengabaian pesan hanya digunakan oleh mahasiswa tahun ke tiga.

3. Strategi meminta bantuan dan penghindaran topik hanya digunakan oleh mahasiswa tahun pertama.

4. Strategi yang paling banyak digunakan mahasiswa tahun ke tiga yaitu meniru dan penciptaan kata.

5. Strategi yang paling banyak digunakan mahasiswa tahun pertama yaitu perkiraan dan meniru.

Penjelasan 1: Strategi penerjemahan langsung tidak digunakan sama sekali.

Penerjemahan literal adalah kondisi strategi di mana pembelajar menerjemahkan kata-per-kata dari bahasa asli mereka. Contoh paling sederhananya, ketika akan menyatakan "Saya tinggal di rumah orang tua," dalam penerjemahan literal menjadi "I live in house parents." Seharusnya, terjemahan dalam 
Bahasa Inggris menjadi “I live in my parents 'house."

Berdasarkan observasi dan wawancara yang dilakukan, peneliti menemukan bahwa mahasiswa Bahasa Inggris Sekolah Vokasi UGM tidak menggunakan strategi penerjemahan literal dalam berkomunikasi dengan mahasiswa asing. Hal ini menunjukkan adanya kesadaran dari pembelajar bahasa bahwa penerjemahan literal dari bahasa asli bisa merusak tata bahasa dari bahasa target, sehingga menimbulkan pesan baru yang keliru. Menariknya, strategi ini justru beberapa kali muncul saat mahasiswa Bahasa Inggris Sekolah Vokasi UGM berkomunikasi dengan sesama teman Indonesianya, namun dalam kalimat yang lebih panjang dan kompleks.

Penjelasan 2: Strategi bicara bertele-tele dan pengabaian pesan hanya digunakan oleh mahasiswa tahun ke tiga.

Yang dimaksud dengan bicara bertele-tele yaitu ketika pembelajar mendeskripsikan karakteristik atau elemen dari sebuah objek atau aksi, alih-alih menggunakan kosa kata atau struktur dari bahasa target yang benar. Misalnya, saat akan menjelaskan kata 'presenter' namun terlupa akan istilah tersebut, mahasiswa menyebut the one who reads some news on $T V$ '. Contoh lain adalah saat mahasiswa menceritakan tentang kopi jos dengan arang, ia kesulitan menemukan kata arang dalam Bahasa Inggris. Dengan strategi ini, ia mendeskripsikan arang sebagai 'the material obtained by heating wood'alihalih mengatakan 'charcoal'.

Dalam strategi ini, pendeskripsian dilakukan untuk mempermudah komunikator dalam penyampaian pesan dengan harapan komunikan dapat menangkap maksudnya. Kemungkinan bagi komunikator menggunakan strategi ini yaitu mereka lupa kata yang dimaksud dan berharap komunikan dapat membantu menemukan kata terebut, atau mereka memang tidak tahu istilah tersebut dalam Bahasa Inggris. Strategi ini digunakan oleh mahasiswa tahun ke tiga, sama sekali tidak digunakan oleh mahasiswa tahun pertama. Berdasarkan pengamatan, hal ini terjadi karena mahasiswa tahun ke tiga memiliki kosa kata yang lebih kaya dibanding mahasiswa tahun pertama. Selain itu, mahasiswa tingkat akhir cenderung lebih percaya diri dalam mengeksplorasi kata-kata didukung oleh pemahaman tata bahasa yang secara umum lebih baik daripada mahasiswa baru.
Adapun strategi pengabaian pesan terjadi saat komunikator sudah berusaha untuk berkomunikasi atau membicarakan sebuah konsep, namun tidak mampu untuk melanjutkan dan memutuskan untuk menghentikan pembicaraan. Misalnya, saat diminta untuk mendiskusikan tentang program siaran TV di negara masing-masing, mahasiswa Bahasa Inggris SV UGM sebagai komunikator mencoba menjelaskan program siaran TV di Indonesia yang menarik. Namun demikian, saat menemui kesulitan saat menceritakan detail acara, komunikator mengatakan 'never mind' sebagai tanda bahwa ia tidak ingin melanjutkan pembicaraan karena kesulitan menemukan kata atau kalimat yang tepat dalam Bahasa Inggris. Dalam momen ini, peneliti menemukan bahwa mahasiswa tahun ke tiga cenderung terbuka dan mau membicarakan berbagai topik (alih-alih menghindari topik) meskipun pada akhirnya berhenti di tengahtengah proses komunikasi dan mengganti dengan topik yang lain.

Penjelasan 3: Strategi meminta bantuan dan penghindaran topik hanya digunakan oleh mahasiswa tahun pertama.

Teknik yang ke tiga yaitu teknik 'memohon bantuan', di mana komunikator meminta bantuan dengan menanyakan istilah yang benar baik kepada lawan bicaranya maupun kepada orang ke tiga. Mahasiswa tahun pertama sering meminta bantuan dengan kalimat 'What is ... in English?' 'How to say ...?' dan kadang-kadang mereka menggunakan Bahasa Indonesia seperti 'Apa itu ...?' 'Bahasa Inggrisnya ... apa ya?' di tengah-tengah proses komunikasi dengan Bahasa Inggris.

Dari pengamatan peneliti, bagi mahasiswa tahun pertama, teknik ini sering digunakan saat berkomunikasi dengan Bahasa Inggris dengan siapapun; tidak hanya ketika dengan mahasiswa asing. Kemungkinan besar terjadinya penggunaan strategi ini adalah karena mahasiswa baru belum semua terbiasa menggunakan Bahasa Inggris di dalam proses komunikasi, baik dalam situasi belajar di kelas maupun obrolan sehari-hari. Oleh sebab itu, mereka cenderung membutuhkan bantuan orang lain untuk menemukan kata-kata yang tepat.

Strategi lain yang hanya digunakan oleh mahasiswa semester satu yaitu penghindaran topik. Penghindaran topik terjadi saat komunikator 
memutuskan untuk tidak terlibat dalam pembicaraan yang topiknya tidak ia kuasai. Berbeda dengan mahasiswa tingkat akhir yang cenderung terbuka untuk berbagai topik meskipun tidak selalu berhasil membicarakan hingga akhir, pembelajar Bahasa Inggris tahun pertama di SV UGM lebih memilih menghindari topik dari awal. Saat diminta untuk membicarakan topik tertentu yang tidak dikuasai baik tema maupun kosa katanya, atau saat ia tidak percaya diri untuk membicarakannya, akan muncul penolakan untuk menghindari topik tersebut dengan menyatakan "Sorry, I don't know about that," atau "Maaf, saya kurang tahu." Dalam beberapa kesempatan, penghindaran topik dilakukan dengan melempar umpan ke rekan yang lain dengan menyatakan "Maybe he/she knows about that," atau "Sepertinya teman saya lebih tau daripada saya, Miss."

Penjelasan 4: Strategi yang paling banyak digunakan mahasiswa tahun ke tiga yaitu meniru dan penciptaan kata.

Strategi meniru terjadi saat komunikator menggunakan komunikasi nonverbal untuk menjelaskan konten leksikal maupun suatu aksi. Misalnya, saat akan mendeskripsikan acara 'Eat Bulaga' di TV, komunikator menirukan aksi yang ditampilkan dalam acara TV tersebut. Komunikator menceritakan secara umum proses berjalannya acara kuis tersebut di TV dengan bantuan gerakan tangan dan menggunakan alat bantu seperti kertas dan bolpoin. Dalam proses komunikasinya, terjadi komunikasi campuran antara verbal dan nonverbal.

Dalam hal ini, proses meniru memberikan kemudahan bagi komunikator untuk memberikan informasi yang valid sesuai niatan komunikator dalam memberikan informasi. Dengan strategi meniru, komunikan ikut berkontribusi dalam menemukan kata yang tepat dalam Bahasa Inggris sehingga keduanya menyepakati dan memahami topik yang sedang dibicarakan. Strategi ini digunakan baik oleh mahasiswa semester 5 maupun semester 1 . Namun demikian, strategi ini lebih banyak digunakan oleh mahasiswa semester 5 .

Strategi ke dua yang paling banyak digunakan mahasiswa tahun ke tiga yaitu penciptaan kata. Penciptaan kata merujuk pada situasi di mana pembelajar sebagai komunikator menciptakan kata baru untuk mengkomunikasikan konsep yang dimaksud. Misalnya, saat membicarakan tentan naskah berita, mahasiswa menggunakan kata 'news text' alih-alih 'news script' di mana penggunaan kata 'script' sebenarnya lebih lazim digunakan dalam perbendaharaan kata di dunia media. Kata 'text' memiliki makna lebih luas dan sering digunakan dalam berbagai konteks, sehingga, saat komunikator kesulitan menemukan kata yang paling tepat, strategi penciptaan kata menjadi pilihan. Bagi komunikator yang berkomunikasi dengan bahasa ke dua, kedua strategi ini sering muncul baik disadari maupun tidak, terutama strategi meniru atau penggunaan komunikasi nonverbal.

Penjelasan 5: Strategi yang paling banyak digunakan mahasiswa tahun pertama yaitu perkiraan dan meniru. Strategi perkiraan terjadi ketika pembelajar sebagai komunikator menggunakan atau memperkirakan suatu kosa kata atau struktur dari bahasa target, meskipun ia tahu bahwa itu tidak benar, tetapi memiliki fitur semantik yang sama dengan kosa kata yang diinginkan. Misalnya, saat membicarakan tentang proses pembuatan video, komunikator menggunakan istilah 'maker' alih-alih 'videomaker' untuk menjelaskan seseorang yang membuat video.

Dalam percakapan sehari-hari menggunakan Bahasa Indonesia dengan sesama orang Indonesia, seringkali seseorang menghilangkan beberapa kata dengan asumsi bahwa komunikan sudah mengerti maksudnya. Misalnya, komunikan ingin mengatakan, "Saya suka dengan video tersebut karena pembuat (video)nya adalah idola saya." Dalam Bahasa Indonesia, kata 'video' setelah kata 'pembuat' tidak diucapkan namun pesan tersebut secara keseluruhan sampai kepada komunikan yang memiliki bahasa asal yang sama. Kemudian saat diterjemahkan dalam Bahasa Inggris dan disampaikan kepada lawan bicara yang memiliki bahasa asli yang berbeda, seringkali keutuhan kata tersebut diabaikan atau tidak digunakan karena lupa / tidak tahu sehingga muncul kata yang maknanya lebih umum atau agak mirip. Dalam hal ini, komunikator telah berusaha mencari kata yang cukup sepadan untuk menjelaskan kekurangtahuannya dalam penerjemahan ke dalam bahasa target. Bagi mahasiswa tahun pertama Bahasa Inggris SV UGM, mereka cenderung menggunakan strategi ini dengan memilih kata yang umum karena perbendaharaan kata mereka cenderung masih terbatas. 
Selanjutnya, strategi yang digunakan oleh mahasiswa tahun pertama adalah strategi meniru. Strategi ini adalah strategi yang paling banyak digunakan mahasiswa tahun ke tiga. Sebagaimana telah dijelaskan sebelumnya, strategi ini melibatkan komunikasi nonverbal yang bermacam-macam. Beberapa mahasiswa memilih untuk mempraktikkan apa yang mereka coba jelaskan, sebagian lain ada yang mencari maknanya di kamus kemudian menunjukkan kepada komunikan terkait kata yang mereka maksud. Cara ini juga mereka gunakan saat yang terjadi adalah komunikan tidak mampu menangkap yang dikatakan oleh komunikan karena perbedaan aksen atau ketika komunikan memang tidak memahami kata tersebut. Beberapa mahasiswa menyebutkan bahwa mereka menggunakan bolpoin dan kertas sebagai media untuk mendukung mereka dalam menyampaikan pesan kepada komunikan.

Adapun strategi yang juga digunakan mahasiswa dari dua tahun angkatan tersebut adalah Pengalihan Bahasa. Strategi pengalihan bahasa terjadi ketika komunikator menggunakan bahasa asli dan mencampurkannya dalam penyampaian pesan berbahasa Inggris. Strategi ini terjadi ketika komunikator kesulitan menemukan terjemahan Bahasa Inggris namun ingin terus melanjutkan menyampaikan pesan yang sudah dipikirkannya.

Secara keseluruhan, komunikasi yang dilakukan oleh mahasiswa Bahasa Inggris Sekolah Vokasi UGM dan mahasiswa pertukaran asing dari Cheng Du Textile College dapat dikatakan berhasil. Hal ini dapat dilihat dari hasil penugasan yang diberikan peneliti saat kelas yang melibatkan kedua belah pihak berjalan. Peneliti menemukan bahwa dari proses komunikasi yang mereka lakukan baik di dalam maupun di luar kelas, mereka berhasil menerjemahkan pesan dari dosen pengampu dan menyelesaikan tugas dengan baik dan benar.

Terlepas dari inti dari penelitian ini, peneliti melakukan wawancara terhadap mahasiswa Bahasa Inggris Sekolah Vokasi UGM yang terlibat dalam kegiatan ini, terkait apa yang mereka rasakan dengan adanya kesempatan untuk berkomunikasi dengan mahasiswa pertukaran asing. Sebesar $81 \%$ dari mahasiswa semester 1 Bahasa Inggris Sekolah Vokasi UGM menyatakan rasa gugup, sementara sisanya merasa tertarik. Namun demikian, bagi mahasiswa semester 5 atau tahun terakhir, $46 \%$ menyatakan tertarik, 23\% menyatakan biasa saja, dan $31 \%$ menyatakan menemui kesulitan.
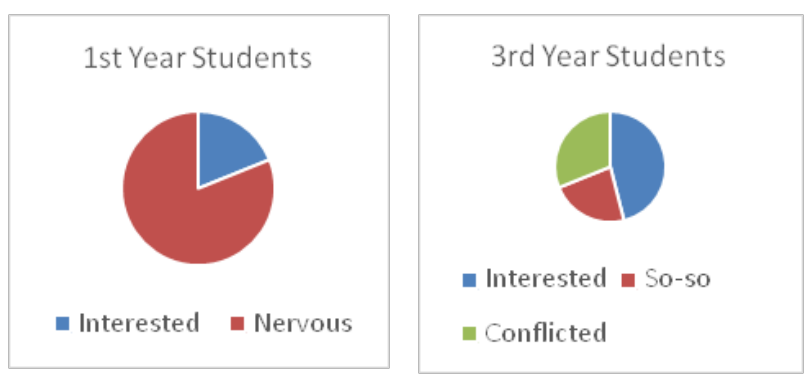

\section{Grafik 2. Perasaan mahasiswa Bahasa Inggris Sekolah Vokasi UGM dalam berinteraksi dengan mahasiswa pertukaran asing dari CDTC China}

Bagi mahasiswa semester pertama, kegiatan ini adalah kali pertama mereka mendapat kesempatan untuk berbicara dan bekerja sama langsung dengan mahasiswa asing. Sebagian besar mereka merasa gugup karena memikirikan tentang kendala bahasa dan budaya. Sisanya sebesar $19 \%$ merasa tertarik dengan kesempatan berbicara dengan orang asing itu sendiri, terlepas dari memikirkan kendala yang mungkin akan terjadi.

Sementara bagi mahasiswa tingkat akhir, mereka telah mendapat kesempatan untuk berbicara dengan English native speaker karena Program Studi Bahasa Inggris SV UGM menyediakan pengajar asing berbahasa Inggris mulai dari semester dua. Bagi mahasiswa yang merasa tertarik, mereka cenderung ingin menguji kemampuan mereka dalam berbahasa Inggris melalui berbicara dengan orang asing. Sementara bagi yang merasa menemui kesulitan, hal itu terlebih kepada kesulitan dalam memahami aksen mereka, serta membuat mereka paham apa yang komunikator maksud. Dalam wawancara disebutkan, seringkali komunikator harus mengulang kata sampai akhirnya komunikan mengerti. Situasi ini membuat sebagian komunikator merasa kurang bisa menikmati proses komunikasi dengan komunikan.

\section{KESIMPULAN}

Dari hasil penelitian yang telah dilakukan, peneliti menemukan bahwa mahasiswa tahun pertama menggunakan strategi perkiraan, penciptaan kata, pengalihan bahasa, meminta bantuan, meniru, dan penghindaran topik. Mereka cenderung lebih 
tertarik untuk berbicara dengan mahasiswa asing, terlepas dari mana mereka berasal. Sementara itu, mahasiswa semester akhir menggunakan strategi perkiraan, penciptaan kata, berbicara bertele-tele, pengalihan bahasa, meniru, dan pengabaian topik. Sebagian merasa tertarik untuk berkomunikasi dengan mahasiswa dari Cheng Du Textile College China, namun merasa kurang tertantang (dalam menggunakan Bahasa Inggris yang baik dan benar).

Dari kesimpulan di atas, Program Studi Bahasa Inggris SV UGM dapat mempertimbangkan untuk membedakan asal negara bagi peserta pertukaran mahasiswa asing bagi mahasiswa semester baru dan semester akhir. Keduanya memiliki karakteristik dan mental yang berbeda dalam menghadapi mahasiswa asing yang bekerja bersama mereka di dalam kelas. Selain itu, Program Studi Bahasa Inggris SV UGM dapat mengevaluasi mata kuliah yang berfokus pada peningkatan kosa kata untuk bisa lebih memberikan penekanan pada mata kuliah tersebut. Kemudian, menyediakan pengajar penutur asing sejak semester awal juga bisa menjadi masukan agar para mahasiswa menjadi lebih percaya diri saat menerima mahasiswa asing atau menjadi peserta pertukaran mahasiswa di negara lain.

\section{DAFTAR PUSTAKA}

Cohen, Louis. (2004). A Guide to Teaching Practice. London: Routledge.

Dwijowijoto, Riant Nugroho. (2004). Kebijakan Publik Formulasi, Implementasi dan Evaluasi. Jakarta: PT Elex Media Komputindo Kelompok Gramedia.
Effendy, Onong Uchjana. (2008). Ilmu Komunikasi: Teori dan Praktik. Bandung: PT Remaja Rosdakarya.

Ellis, Rod. (1994). The Study of Second Language Acquisition. Oxford: Oxford University Press.

Gudykunst, William B. (1993). "Toward a Theory of Effective Interpersonal and Intergroup Communication: An Anxiety/Uncertainty Management (AUM) Perspective" in Intercultural Communication Competence, $\mathrm{R}$. L. Wiseman and J. Koester (eds.). CA: Sage.

Nichols, Rebekah. (2014). "Motivating English Language Learners: An Indonesian Case Study" in Master of Education Program Theses. Paper 52

Rogers \& Kincaid. (1981). Communication Networks: Toward a New Paradigm for Research. New York: Free Press.

Shoemaker et al. (2003). How to Build Social Science Theories. California: Sage Publications.

Tarone, Elaine. (1981). "Some Thoughts on the Notion of Communication Strategy" in TESOL Quarterly. Vol. 15, No.3.

Tubbs \& Moss. (2001). Human Communication 2: Konteks-konteks Komunikasi. Bandung: PT Remaja Rosdakarya.

Widjaja, A.W. (2002). Komunikasi: Komunikasi \& Hubungan Masyarakat. Jakarta: Bumi Aksara. 